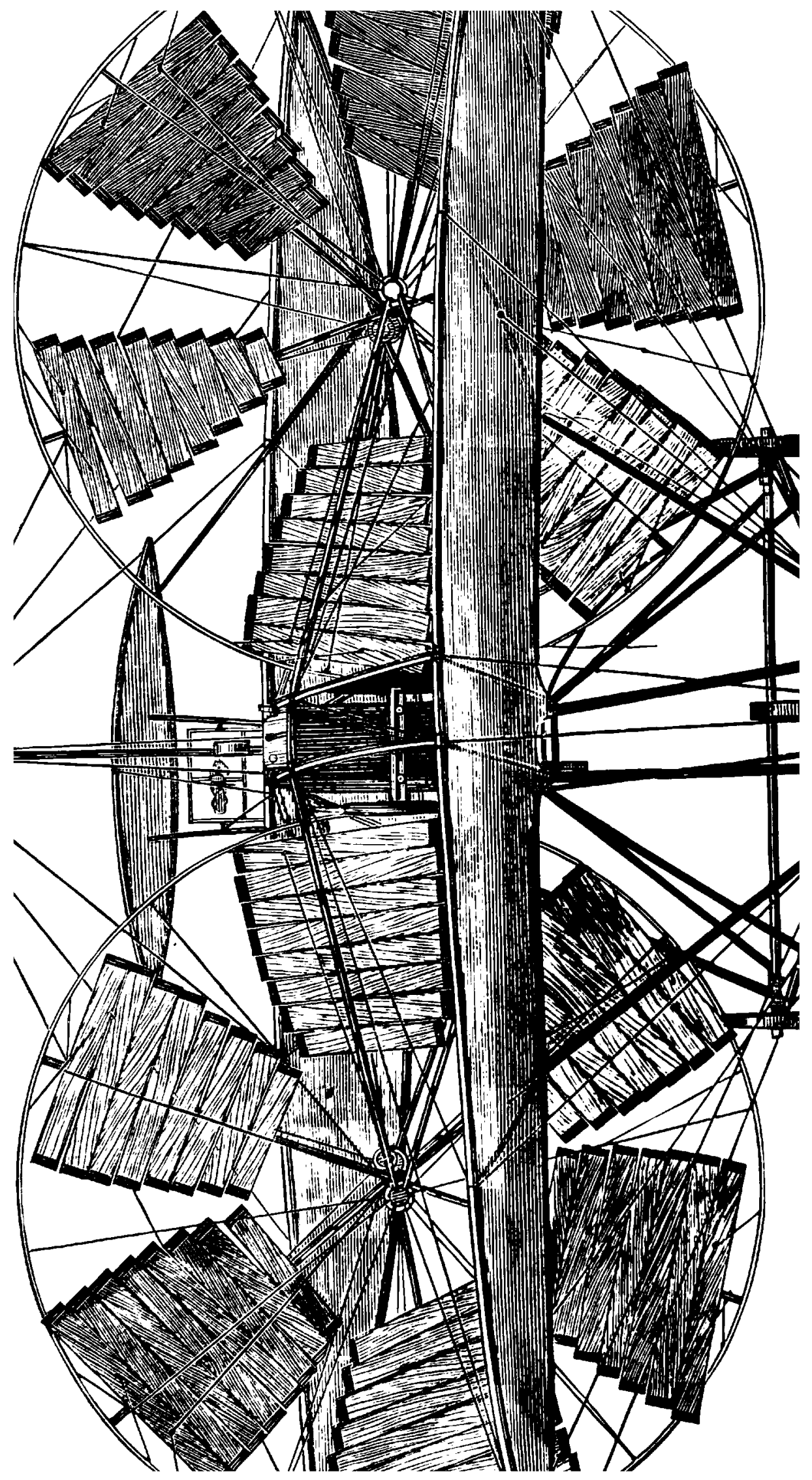




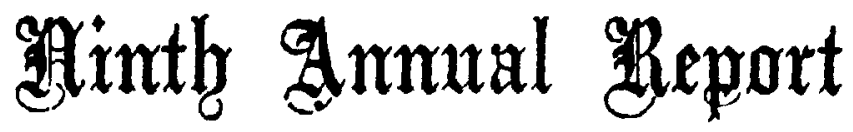

OF THE

\section{AËRONAUTICAL SOCIETY}

or

\section{GREAT BRITAIN.}

FOR THE TEAR 1874.

PRINTRD BT

HENRY S. RICHARDSON,

GRERNWICH, 
THE

AËRONAOTICAL SOCIETY OF GREAT BRITAIN.

\author{
但resituent, \\ HIS GRAOE THE DUKE OF ARGYLL, K.T. \\ Eice:挜residents, \\ HIS GRACE THE DUKE OF SUTHERLAND. \\ RIGHT HON. THE EARL OF DUFFERIN. \\ LORD RICHARD GROSVENOR, M.P.
}

Fignorary Dectetary,

FRED. W. BREAREY, Esq.

醕onoraty Solícitors,

Mrgans. MATTHEWS \& GREETHAM, 26, Bedford Row.

Taumail,

A. ALEXANDER, Esq, C.E., M.A., Sheffield.

FRED. W. BREAREY, Esq., Maidenstone Hill, Blackheath. SIR CHAS. T. BRIGHT, F.R.A.S., 26, Duke St., Westminster. CHARLES BROOKE, Esq., M.A., F.R.S., 16, Fitzroy Square. JOHN BROWNING, Esq., E.R.A.S., F.R.M.S., 111, Minories, and

63, Strand.

MAJOR BURNABY, Royal Horse Guards.

HUGH W. DIAMOND, Ese., M.D., F.S.A., Twickenham. JAMES GLAISHER, Esq, F.R.S., F.R.A.S., Blackheath. Rrar-Adurral Lord JOHN HAY, C.B., 149, Piccadilly. W. H. LE FEUVRE, EsQ., C.E., F.R.G.S., 28, Brunswick Gardens. MAGNUS OHREN, EsQ., A.I.C.I., F.C.S., Lower Sydenham. LORD LINDSAY, F.R.A.S., 47, Brook Street.

F. H. WENHAM, Esq., C.E., V.P.R.M.S., Padnall Hall, Chadwell,

Essex.

HENRY WRIGHT, Esq., Stafford House, St. James'. WITH POWER TO ADD TO THEIR NOMBER.

Member's Subscription, $£ 1.1$ s. per annum, dating from the day of Election Ladies may become Associates upon the same terms. 